\title{
Kinas økonomiske model ved vejs ende
}

\section{Kim Rathcke Jensen}

Kinas succesrige økonomiske model støder nu på sine grænser. Det ved partiet, men der er stor modstand imod de dybtgående reformer, der er nødvendige for beholde BRIKS's førertrøje. Xi Jinping har store ambitioner

Det er lidt over et år siden, at Kina fik nye ledere. Siden da har det store spørgsmål været, om de ville være i stand til at lancere reformer, der er nødvendige for at løse de enorme problemer i verdens næststørste økonomi.

En del af svaret kom i midten af november. Her sluttede det politiske topmøde i Beijing, som officielt hed Det Tredje Plenum. Det vil sige, at det er tredje gang, at den politiske top i Kinas Kommunistparti mødes, efter de kom til magten i november 2012.

Forventningerne var store. Ved hvert magtskifte kommer Det Tredje Plenum efter et års tid, hvor de nye ledere har haft tid til at cementere og udbygge deres magt og netværk. Det var ved et tredje plenum, at de store økonomiske reformer, der åbnede Kina mod omverdenen, blev lanceret i 1978. Og det samme i 1993, hvor reformerne af den statslige sektor blev startskuddet til de seneste to årtiers økonomiske succes og høje vækst. Mødet i 2013 kan måske ende i samme historiske liga.

Og det er der brug for. I BRIKSlandene er det Indien og Kina, der har været de hurtigst voksende økonomier, som i 2010 stod for sammenlagt 20 procent af verdens bruttonationalprodukt. Og i især Kina er det gået stærkt. Men hvis det skal fortsætte, er der brug for omfattende reformer. Der er bred enighed blandt økonomer om, at den økonomiske model, der har kørt Kina frem i de seneste årtier, er kommet til vejs ende. Partiet kender proble- 
merne. De 373 partimedlemmer, der sidder øverst i etpartistatens hierarki, og som styrer nationen med de mere end 1,3 milliarder mennesker, sluttede det fire dage lange møde med et dokument, der udstikker den politiske og især økonomiske kurs for det næste årti.

Der er i alt 60 punkter i reformerne, der skal effektivisere og reformere økonomien fra at være baseret på investeringer til en, der er drevet af forbrug. Overordnet er der fem vigtige punkter.

\section{Børn og urbanisering}

Der bliver i nogen grad løsnet for etbarns-politikken, så par, hvor den ene forælder er enebarn, kan få to børn. Men det er dyrt at have børn i dagens Kina. For eksempel på grund af forsikringer og omkostninger til skole, så de fleste eksperter forventer mere et bump end boom i antallet af børn, der skal kompensere for de næste årtiers skrumpende arbejdsstyrke.

Kina vil ændre sit hukou-system (husholdningsregistreringssystemet. Red.). I dag er migrantarbejdere bundet til deres hjembyer og mister sociale rettigheder, når de flytter til byerne for at arbejde. Reformerne vil gøre arbejdsstyrken mere fleksibel og forstærke urbaniseringen.

Bønder får flere rettigheder til deres jord. I dag er det etpartistaten, der ejer og kontrollerer jorden, og lokalregeringerne har tjent milliar- der på at tvangsflytte bønder og $\mathrm{i}$ stedet bygge fabrikker eller byområder. Reformerne lægger op til, at bønderne nu vil kunne få en form for rettighed til jorden og fx også tage lån i jordstykkerne.

Der er også lagt op til store reformer af det finansielle system, så for eksempel private også vil kunne oprette banker. Samtidig vil der blive slækket på kontrol af priserne på eksempelvis el og vand.

Med reformerne kommer de store statsejede selskaber også til at betale mere af deres indtægter tilbage til etpartistaten, der blandt andet vil bruge dem på sociale ydelser. Private virksomheder skal spille en større rolle i økonomien generelt og i de sektorer, hvor de statskontrollerede selskaber ofte har monopoler.

Det er de fem punkter i planen. Men som altid i Kina er der forskel på, hvad etpartistaten siger, og hvad der så i virkeligheden bliver implementeret. Så har generalsekretær Xi Jinping og de seks andre medlemmer i Politbureauets Stående Udvalg de politiske muskler til at kunne gennemføre dem og føre økonomien i en ny retning?

\section{Mange stritter imod}

Modstanden er stor. For eksempel fra de 113 statsejede selskaber, der i de seneste ti år under Xi Jinpings forgænger, $\mathrm{Hu}$ Jintao, fik lov til at vokse sig stadigt større både økonomisk, samt når det kommer til poli- 
tisk magt. Deres ledere, der i etpartistaten har rang af viceministre, og som veksler mellem direktørposter og politiske embeder som guvernører i provinserne, står i spidsen for et system, der ikke blot vil lade deres magt blive afmonteret.

Men Xi Jinping er måske manden, der kan gøre det, mener nogle analytikere. For eksempel Arthur Kroeber, der er direktør i analysefirmaet Gavekal Dragenomics i Beijing. Xi Jinping har i det seneste år blandet andet gennemført en omfattende kampagne mod korruption, der har vist ham som en mere magtfuld og visionær leder end sin forgænger Hu Jintao, skriver Arthur Kroeber i en analyse til amerikanske Brookings Institute.

"Hans mål er at redefinere de grundlæggende mekanismer i markedet og regeringen, og ved at gøre det at etablere sig som den mest markante kinesiske leder siden Deng Xiaoping", skriver Arthur Kroeber.

"Det er endnu ikke sikkert, om Xi kan gennemføre sine store ambitioner, eller om det er den rigtige recept på en kur til Kinas voksende sociale og økonomiske problemer. Men en ting er sikkert: Man kan ikke beskylde Xi for at tænke for småt”, mener Arthur Kroeber.

Siden 1990'ernes reformer er der kommet skarp konkurrence på flere markeder, men ikke når det kommer til de tre ressourcer energi, investeringer og jord, hvor etpartista- ten har bevaret kontrollen over både udbydere og pris.

Det er det, som Xi nu i nogen grad vil gøre op med. Hvis det lykkes, så vil det give et markant løft til den økonomiske effektivitet, men samtidig frarøve centralregeringen i Beijing vigtige styreredskaber, som der står i analysen på Brookings Institute.

"Kort sagt, så synes visionen at være, at man bevæger Kina langt tættere på en økonomi, hvor regeringen spiller en regulerende rolle mere end en direkte interventionistisk rolle", skriver Arthur Kroeber.

Men kritikere mener også, at dokumentet fra det tredje plenum mangler at gøre op med de magtfulde statsejede virksomheders rolle i økonomien. De store mastodonter og monopoler er skyld i, mener kritikerne, faldende produktivitet og voksende gæld, og de har adgang til lån fra statskontrollerede banker og anden kapital, som kun giver et uhyre begrænset afkast. Og her er dokumentet klart. Selv om de statsejede virksomheder skal gå fra i dag at betale cirka ti procent af udbyttet tilbage til 30 procent i de næste år, så bliver de ikke privatiserede, og kommer stadig til at spille en rolle $\mathrm{i}$ 2022, hvor Xi Jinping skal træde tilbage efter ti år på posten.

\section{Det tabte årti}

De fik deres magt under generalsekretær $\mathrm{Hu}$ Jintao og ministerpræsi- 
dent Wen Jiabao, der ikke var magtfulde nok til at bekæmpe dem. Mange taler om deres år ved magten som 'det tabte årti', og prikken over i'et var deres sidste regeringsår, som var præget af magtkampe mellem det stadigt stærkere magtapparat, ministerier og statsejede virksomheder.

Derudover kommer interessegrupper som provins- og lokalregeringer samt magtfulde rigmænd og netværk af partipolitikere, der alle i dag er mere magtfulde interessegrupper end i 1990'erne, da den stærke og beslutsomme Zhu Rongji lancerede reformerne, der dengang pillede de statsejede virksomheder fra hinanden, som indtil da havde været en hjørnesten i den kinesiske kommunisme.

Siden han kom til magten har Xi forsøgt at sende et klart signal om, hvem der er ved magten. Blandt andet har Xi's kampagne mod korruption gået efter nogle af de mest magtfulde personer i den vigtige olieindustri og den største af de statsejede virksomheder, China National Petroleum Corporation, der har over 1,6 millioner ansatte og målt på markedsværdi er verdens næststørste selskab. Beskeden? Xi Jinping har tøjlerne, og han vil gennemføre sine reformer.

Selvom Xi Jinping er ved at markere sig som en af de stærkeste ledere siden Deng Xiaoping, så er han ikke enevældig. Store beslutninger og politiske manøvrer træffes i før- ste omgang i partiets 'Politbureauets Stående Udvalg', der er de øverste syv personer i partiet, som er spydspidsen i et forgrenet netværk af hemmelige alliancer og forbindelser.

Men selv om der er forskellige interesser og fløje i kommunistpartiet, så er der ingen uenighed i spørgsmålet om, hvem der skal sidde ved magten i Folkerepublikken Kina. Udgangspunktet for alle reformerne - og årsagen til de fraværende politiske og demokratiske af slagsen - er, at Kinas Kommunistparti skal styrke og bevare sit magtmonopol. Det kræver økonomisk vækst. Blandt andet fordi det ellers giver social uro.

Det så man blandt andet $\mathrm{i}$ landsbyen Wukan i 2011, hvor tusinder lokale indbyggere demonstrerede og smed kommunistpartiets ledere ud af byen, fordi de lokale bønder havde fået konfiskeret deres jord. Det er en af de mest almindelige sociale konflikter i dagens Kina.

\section{Problemernes knude}

"Mange af disse demonstrationer er relateret til utilfredshed hos de lokale indbyggere, der kan se, hvordan de lokale embedsmænd tjener penge på udvikling af områderne", siger Richard Herd, der er cheføkonom for Kina i OECD.

"Kina er på mange måder et meget usædvanligt land forstået på den måde, at det har været i stand til ret ofte at ændre sin udviklingsmodel. 
Når der er begyndt at opstå problemer med den ene model, så har man introduceret en ny", siger Richard Herd.

Kina er en knude af problemer. For eksempel faldende eksport, dalende effektivitet, en skæv demografi med flere ældre og færre unge, stigende lønninger, store monopoler, voldsomme og kostbare miljøproblemer, lokalregeringers gæld for blot at nævne nogle få. Og det skal løses med en økonomisk model, som i følge flere analytikere er kommet til vejs ende.

"Indtil nu er der ikke fundet nogen troværdige alternativer til vækst gennem investeringer", siger Michael Pettis, der er en kendt Kinaekspert og økonom, som blandt andet er tilknyttet Carnegie Endowment for International Peace.

Et simpelt eksempel. Når der er en muddervej i en landsby, giver det god mening at lægge godt grus på den, så de lokale kan få bedre transport og eksempelvis hurtigere få varer ind og ud af byen. Endnu bedre er det at asfaltere vejen. Måske er der endda også behov for at udvide den til en landevej. Investeringerne tæller som økonomisk vækst i statistikkerne, og de giver samtidig reelle og markante løft i produktiviteten.

Men Kina er nu kommet til et punkt, hvor man bygger en motorvej i stedet for. Eller højhastighedstog. Og måske en bro. Det er ikke holdbart, siger Michael Pettis. Især ikke når efterspørgslen efter billige varer fra Kina er faldende i Vesten.

"Derfor bliver man nødt til at ændre kilden til vækst til et mere bæredygtigt indenlandsk forbrug", mener Michael Pettis. Det kan blive svært. Blandt andet fordi det betyder, at Kina skal flytte vækst og velstand over til familier og forbrugere.

"Indtil i dag, var det som var godt for eliten også godt for nationen. Men i de kommende år er elitens interesser ikke de samme som resten af landets", siger Michael Pettis.

Så kan partiet og Xi Jinping reformere Kina og økonomien? Måske. Men ikke engang Xi kan svare sikkert på det spørgsmål.

Kim Rathcke Jensen er dagbladet Politikens korrespondent $i$ Beijing. 